\title{
The "Jian" Spatial Unit, as the Main Characteristic for Measuring Individual Structures and Architectural Complexes in China
}

\author{
Marianna Shevchenko, ${ }^{1, *}$ \\ ${ }^{1}$ Scientific Research Institute of Theory and History of Architecture and Urban Planning, Branch of the Central \\ Institute for Research and Design of the Ministry of Construction and Housing and Communal Services of the \\ Russian Federation, Moscow, Russia \\ *Corresponding author. Email: china-arch@yandex.ru
}

\begin{abstract}
This article examines the question of the interpretation of the term "jian"- a span, interval, or a measurement of space in between (points, columns, supports, or objects) - in traditional Chinese architecture. This term was used [as a spatial unit] in Chinese treatises, to describe the spatial dimensions of large architectural complexes for various purposes, as well as to measure the amount of damage from a potential fire and to describe the scale of destruction. The amount of jian, which an individual structure spanned also possessed a certain value, and varied in accordance with changes in the prevailing rituals of Chinese society. Over time, the number of spans the main façade of a building possessed, become an important characteristic and indicator of status. A comparison of the instructions in the "Yingzao Fashi" treatise, with various surviving architectural complexes, revealed that from the beginning of the 11th to the beginning of the 20th centuries, the instructions described in Yingzao Fashi, concerning the number of jian were implemented in the overwhelming majority of extant cases.
\end{abstract}

Keywords: The jian spatial unit, Chinese architecture, Architectural complexes, Separate buildings, Wooden frame architecture.

\section{INTRODUCTION}

The term jian is widely used in Chinese architecture, both traditional and modern. However, careful study reveals that it is rather polysemantic, and thus, for many translators of the Chinese language, difficulties may arise in understanding the exact context in which this term is used. Literally the logograph jian i means "the space in between". It is not rare to find the word "kaijian" (开间), used with the same meaning, however, judging by historical records, this word is of a rather late origin, dating to approximately the end of the $19^{\text {th }}$ and beginning of the $20^{\text {th }}$ century.

But the a jian span or interval, described in written sources, could mean either a room, or the space between columns and/or supports, which are obviously completely different things. A building in question could possess five rooms, or it could have only one room, but it could still be said to have five spans (jian). Analysis of Chinese historical texts reveals that the word jian is used to mean "room", in those buildings where load-bearing walls are employed. An example of this use of the word can be found in the description of Neolithic buildings, discovered in the 1970s, in the Xiawanggang settlement of Xichuan County, of the Henan Province, which possessed load-bearing walls and many rooms; in the largest building, their number reached 32, and when describing the layout of this structure, Chinese scientists used the term jian to mean "room" [1].

In the context of meaning "span or interval", the term jian was used to describe timber framed structures. Due to the fact that a timber frame system had become the leading structural form in Chinese architecture, as well as the fact that it was widely described in classical treatises on construction, over time the understanding of the term jian to mean "span" or "interval" began to prevail. Moreover, the main span was considered to 
run along the main extended facade of buildings, and not along the depth of the structure.

\section{THE USE OF THE TERM "JIAN" TO RECORD THE MEASUREMENTS OF ARCHITECTURAL COMPLEXES}

In recorded texts, you can often find descriptions of large monastic or palace complexes, where their size is measured in "jians", that is to say, in spans, as a defined spatial unit. When one or another ruler expanded the palace, and added additional structures to it, their total length was also indicated in jians, often without specifying the number of structures proper. So, according to archival records, after the expansion of the imperial palace in Shenyang, during the reign of the Qing Dynasty Emperor Qianlong in 1748, "new multileveled chambers, towers and halls of the palace, with a total length of more than 100 jian were erected" [2]. Also, when describing the temples on Mount Taishan, the Song Dynasty era encyclopedia Taiping Yulan, compiled in the period 977-983, says that "temples and expansion wings had measured more than 30 spans" [3]. In the treatise written by Wang Zinian (?-390) "Shi Yi Ji" or "Researches into Lost Records", the following description is given: "Mount Dongting floats above the water, and underneath there are golden halls spanning several hundred jian, where therein dwelleth the daughters of the heavenly king" [4]. As we can see, none of the descriptions given specifies the number of individual structures and/or their location. Only the total number of jian is given to describe the size of the entire complex.

Also, when accounting for damage caused by fires in palace complexes, authors of historical chronicles recorded the amount of the damages by the number of burnt jian cells. There are archival records of a fire in the imperial palace of Beijing, which says that the fire spread across a total of 42 jian, spanning various buildings, including the Zhendongmen gate, Chonglou tower, the southwest galleries of the courtyard, the Xihemen Gate, and the vaults. It was also said concerning a fire in the Yanxigong palace, that 25 jian were burned [5]. The same concept could be applied to not only palaces, but also civil administrative buildings. Thus, in the "Qing Shi Gao" or the "Draft of the History of the Qing Dynasty", compiled in 1927, it is said that during the reign of Emperor Puyi, a fire broke out in Gaolan county, as a result of which, more than 60 jian cells of the local government building were burned down [6]. This measurement could also be applied to heterogeneous urban buildings, including residential buildings. The "History of Ming" says that at the beginning of the Hongzhi era (late $15^{\text {th }}$ century), more than 2,500 jian [of various] buildings were burned by fire, and more than 100 people were killed [7]. Most likely, the jian spatial unit served as a general measurement for calculating the cost of construction or an amount of damage incurred, and therefore, great attention was paid to the number of jian during new construction works, or in case of damages to existing structures.

It is worth clarifying here, that the jian was understood as a spatial cell, which included not only two adjacent pillars, but also all the structure of the building located behind the façade jian: this included internal and rear supports, and roof structures, which together formed what was called the "frame joint", which formed the characteristic cross-section of the building ("Figure 1"). Since the Song Dynasty, the forms of such sections have been quite strictly regulated, and thus, the calculation of the cost of the structure (and therefore any losses) could very well be carried out based on the number of jian [8].

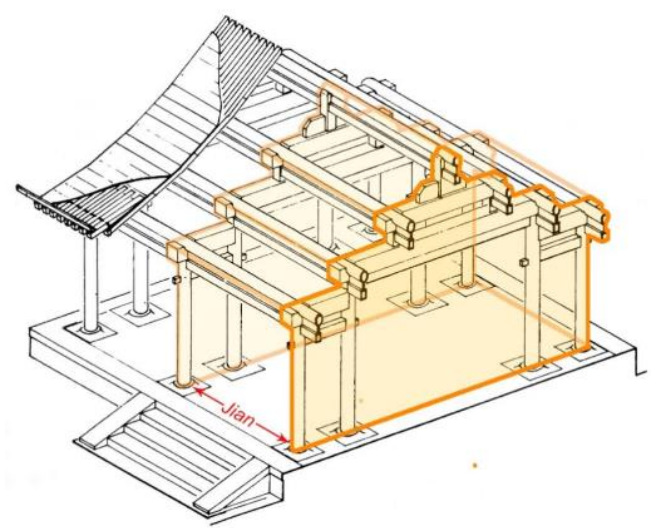

Figure 1 The jian span, as a spatial unit and/or structural cell. (The authors original drawing). 


\section{THE NUMBER OF JIAN IN INDIVIDUAL BUILDINGS}

Since antiquity, concerning individual buildings, the number of jian along the main facades of buildings has been given special attention. Early architecture was dominated by an even number of jian in the main structures of architectural complexes. This was due to an ancient ritual in which two staircases were arranged in buildings: a master on the east side, and a guest in the west, which naturally led to the organization of an even number of jian. This type of structure is demonstrated by buildings from the Bronze Age (15-11 centuries BC), as well as palace and temple buildings of the Zhou (11-3 centuries BC) and Han (3 century BC to 3 century AD) Dynasties [9]. But with the collapse of the empire, and the onset of a period of internecine conflicts, which is called the era of the Northern and Southern Dynasties (420589 ), the number of jian in primary structures becomes mostly odd, so that a jian spans the center of the building, and not the pillars, as in early structures. Accordingly, the old layout system with two staircases also gives way to a new system with one central staircase, or less often, one with three staircases, one of which is located by necessity in the center, opposite the central jian. At the same time, the idea is formed that the more significant the structure, the larger it should be, and therefore, it should have more jian.

In traditional Chinese architecture, the jian span, along with the shape of the roof, early on becomes one of the most important characteristics of a building. By the time of the Song Dynasty, that is, by the beginning of the $11^{\text {th }}$ century, a system of ranking structures was being developed in Chinese architecture, in which the number of jian played one of the leading roles. In the treatise Yingzao Fashi, it is written that: "The first rank ... includes dian-hall type buildings, numbering in spans from nine to eleven; the second rank ... dian-halls numbering from five to seven (spans); the third rank ... dian-halls from three to five, or seven-span buildings of the tang-hall type; the fourth rank ... includes three-span dian-halls or five-span tanghalls; the fifth rank ... includes small three-span structures of either the dian or tang type" [10]. From this description, we see that the number of jian was associated with the typology of buildings, "dian" or "tang" respectively. The dian-hall and tang-hall structures differed in their constructive scheme. The main difference was the presence of a decorative wooden ceiling in the interiors of buildings of the "dian" type, due to which the internal structures (i.e. the beams, and pillars) were divided into two categories, the first - the visible style - with these decorative supports located below the ceiling level — and the "crude" style, in which these supportive structures are located above the ceiling level. The presence of a ceiling also led to the leveling of the height of the internal supports in the interior, when the supports reached the level of the ceiling, and the rafters were already located above. In halls of the "tang" type, ceilings were not used, so all structures remained open in the interior up to the rafters, and the height of the internal supports also changed, following the slope of the rafters: the internal supports were higher than the external ones.

Halls of the "dian" type were considered a higher rank than the halls of the "tang" type. The number of jian in these buildings also changed accordingly. The fact that the correlation described in the treatise - between the quantity of jian in buildings and the ranking of those buildings - was actually applied in the architecture of the Song Dynasty, and can be observed both by indirect evidence, such as images of buildings on contemporary scrolls and drawings, as well as by extant preserved structures [11].

The fifth chapter of Yingzao Fashi also mentions the existence of thirteen-span halls of the dian type, however, this single mention does not appear in other descriptions regarding the ranking and measurements of structures. There exists evidence of the practical application of thirteenspan halls in palaces of the Tang Dynasty (618907). The foundations of the Hanyuandian Hall of Daminggong Palace to the northeast of the modern city of Xian, discovered by archaeologists, indicate that the throne room of the palace measured 13 jian along the main façade, and was the largest structure of its time. Nevertheless, later buildings provide no evidence of the employment of 13 spans, and in practice, in the most significant structures, the maximum number of spans did not exceed 11. These were structures associated with the emperor, such as the throne rooms of palaces or temples of the emperor's ancestors.

It should be noted, that attention was paid only to the number of jian of the main structures of complexes, erected along the central axis, or distinguished by their special status or purpose; the number of jian secondary buildings, such as the wings on the sides, or galleries possessed, was not given special attention. It was not rare that a 
courtyard would be surrounded by structures possessing a common gallery, along the courtyard façade. In this case, these buildings were conceived only as a frame for the courtyard, and their amount of jian was determined solely by the size of the courtyard, and the constructional requirements, and did not bear any additional symbolic value. Thus, the main courtyard of the imperial palace in Beijing, is surrounded on two sides by galleries, with adjacent side walls, which form a continuous building front. On each side of the courtyard, one four-span building was erected, five five-span and one three-span building, which in total forms 32 spans on each side [12]. There is no pattern or symbolic content in the number of spans of these side buildings.

As for the main buildings of the courtyard, their number of jian was certainly of symbolic significance. The Taihedian Hall measures 11 jian, which was, as noted, the maximum number of jian practically employed. The Baohedian Hall, located to the north of the courtyard, which served the palace complex in an auxiliary function during imperial receptions, is inferior in importance to the Taigedian Hall, and correspondingly, has the lesser number of 9 jian. The Zhonghedian Hall, erected in the center of the architectural ensemble, symbolizes the center or the middle, which is reflected in its name-the Hall of the Central Harmony. Its structure and location reflect the traditional concept of the Five Primary Elements or Phases, (Wuxing), according to which the element of Earth occupies the center. Earth was thought to be the fifth element, and it was located in the center, connecting the other four elements (Fire, Water, Wood and Metal). Therefore, the number 5 eventually became a symbolic expression of the concept of Earth as the center. That is why the central Zhonghedian hall has a square shaped plan, which symbolizes Earth, and along the façades, there are 5 jian on each side, symbolizing the center ("Figure 2"). All three main halls, in turn, were located in the center of the imperial palace, and together they also symbolized the center, therefore the pedestal on which they are installed has the shape of the Chinese character $土$ which means "Earth".

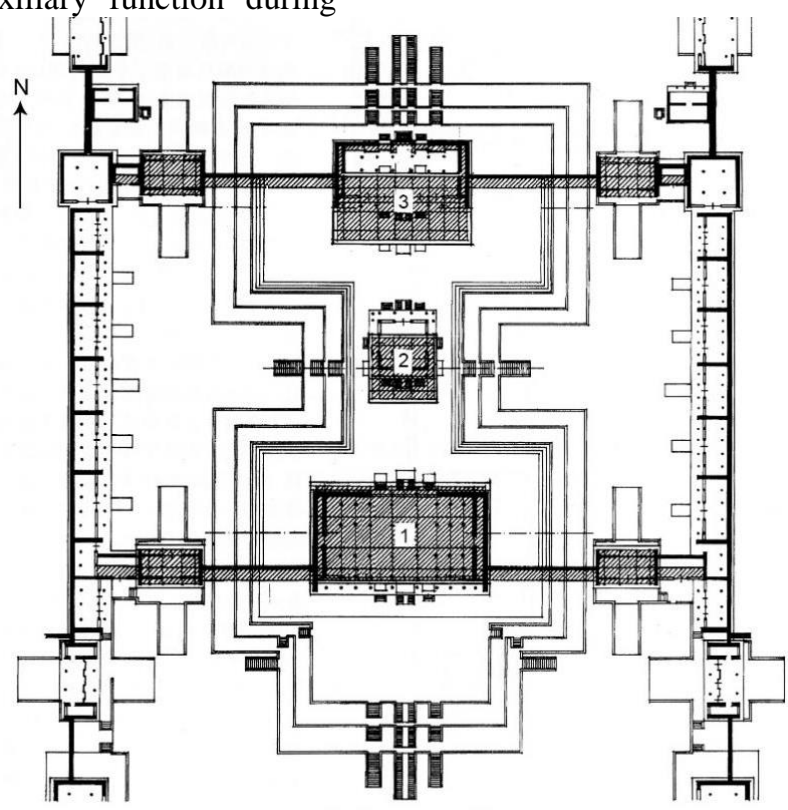

010 $50 \mathrm{~m}$

Figure 2 The Plan of the main courtyard of the imperial palace in Beijing. Shaded lines show the location of buildings during the Ming dynasty. 1-the Taihedian hall, 2-Zhonghedian hall, and 3-Baohedian hall [13].

Gradually certain jian spans are given different specialized names depending on their location. Already in the Yingzao Fashi treatise, you can find different names for certain spans: the central span is called the "dangxinjian" (当心间) and the ones on the sides are called "shaojian" (梢间) [10]. Although in Yingzao Fashi, these designations are given and used not as independent, separate terms, but rather, for the sake of precise communication, to more accurately denote the location of certain structural elements. But in the construction manual "Gongcheng Zuofa Zeli", or "Construction Methods and Rules", compiled in 1734, a rather detailed terminology for naming jian, depending on their location, is already given. Thus, the central span is called the "light span" or mingjian (明间), and the 
adjacent jian is called the "second span" or cijian (次间), and the outermost span is called the "far span" or shaojian (梢间) [14]. However, unlike in Yingzao Fashi, this work does not provide a detailed description of the relationship between the number of jian and the status of the structure, but examination of the actual buildings shows us that even during the reign of the Qing Dynasty, that relationship remained, and did not undergo any or significant changes, compared to the time Yingzao Fashi was written in 1103.

In order to more concretely demonstrate, that the relationship described in the Yingzao Fashi

Table 1. The quantity of jian (spans) according to the treatise Yingzao Fashi [10] and in preserved complexes,

and values that differ from the requirements of the treatise are shaded in

\begin{tabular}{|c|c|c|c|c|c|c|c|c|c|c|c|c|c|c|c|c|}
\hline Dating & \multirow[b]{2}{*}{ 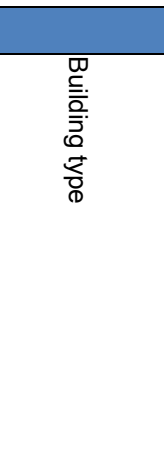 } & 1103 & \multirow[b]{2}{*}{ 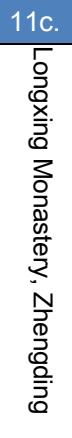 } & \multicolumn{2}{|c|}{$12-13 \mathrm{c}$} & \multicolumn{6}{|c|}{ 14-17 c. } & \multicolumn{5}{|c|}{$18 \mathrm{c}}$. \\
\hline $\begin{array}{l}\overline{8} \\
\bar{d} \\
\overline{0} \\
\overline{0}\end{array}$ & & 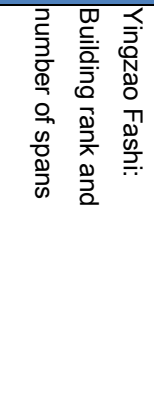 & & 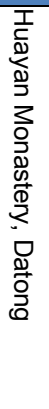 & 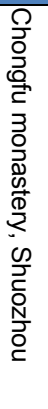 & 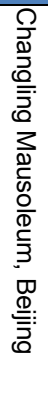 & 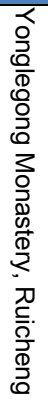 & 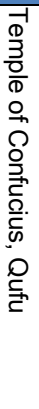 & 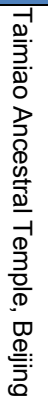 & 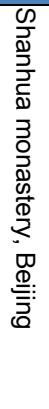 & 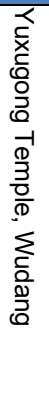 & 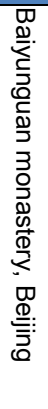 & 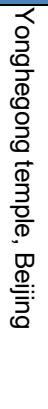 & 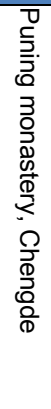 & 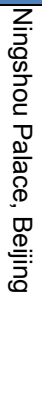 & 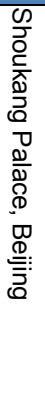 \\
\hline \multirow{2}{*}{ 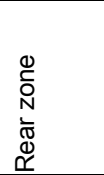 } & Hall & $\begin{array}{l}\text { rank III } \\
\text { 3-7 spans }\end{array}$ & & & 5 & & 5 & 5 & 9 & & & 5 & 7 & 3 & 3 & 5 \\
\hline & Hall & $\begin{array}{l}\text { rank III } \\
\text { 3-7 spans }\end{array}$ & 5 & & & & 5 & 7 & 9 & & 3 & & & & & \\
\hline \multirow{2}{*}{ 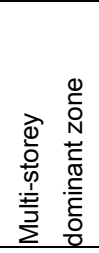 } & Tower & $\begin{array}{l}\text { rank II } \\
5-7 \text { spans }\end{array}$ & 7 & & & 3 & & & & & & & 7 & 7 & 9 & \\
\hline & Pavilion & $\begin{array}{l}\text { rank IV } \\
\text { 3-5 spans }\end{array}$ & 5 & & & & & & & & & & & & & \\
\hline \multirow[b]{3}{*}{ 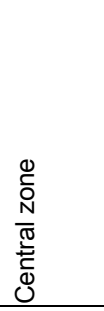 } & Main hall & $\begin{array}{l}\text { rank I-II } \\
7-11 \text { spans }\end{array}$ & 7 & 9 & 7 & 9 & 7 & 9 & 11 & 7 & 7 & 5 & 7 & 7 & & \\
\hline & $\begin{array}{l}\text { Pavilion/ } \\
\text { hall }\end{array}$ & $\begin{array}{l}\text { rank III } \\
\text { 3-7 spans }\end{array}$ & & & & & & 3 & & & & & & & 7 & 5 \\
\hline & $\begin{array}{l}\text { Walk- } \\
\text { through hall } \\
\text { / gate }\end{array}$ & $\begin{array}{l}\text { rank III } \\
\text { 3-7 spans }\end{array}$ & & 3 & 5 & & & 5 & & & & 3 & 5 & & 5 & \\
\hline \multirow{4}{*}{$\begin{array}{l}0 \\
\stackrel{0}{0} \\
N \\
\stackrel{2}{0} \\
\text { Oㄴ }\end{array}$} & Hall & $\begin{array}{l}\text { rank IV } \\
\text { 3-5 spans }\end{array}$ & & & & & & & & & & 3 & & & & \\
\hline & Front hall & $\begin{array}{l}\text { rank II } \\
5-7 \text { spans }\end{array}$ & & 5 & 5 & & 5 & 7 & & 5 & 5 & 5 & 7 & 5 & 9 & 5 \\
\hline & $\begin{array}{l}\text { Small hall / } \\
\text { Pavilion }\end{array}$ & $\begin{array}{l}\text { rank III } \\
\text { 3-7 spans }\end{array}$ & & & 5 & & & & & & & 3 & 5 & 3 & 9 & \\
\hline & Gate & $\begin{array}{l}\text { rank IV } \\
3-5 \text { spans }\end{array}$ & & & & & & 5 & & & 3 & & 3 & & & \\
\hline Dating & & 1103 & 11c. & \multicolumn{2}{|c|}{$12-13 \mathrm{c}$} & \multicolumn{6}{|c|}{$14-17$ c. } & \multicolumn{5}{|c|}{$18 \mathrm{c}}$. \\
\hline
\end{tabular}

treatise, between the number of jian, and the rank of a structure, continued to exist until the end of the Qing dynasty, we compiled "Table 1" below. This table contains the descriptions from Yingzao Fashi regarding the quantity of jian and the ranking of buildings, cross referenced with various extant architectural complexes of differing purposes (ritual, palace, burial) which were preserved in relative integrity. They are presented, placed in chronological order, starting from the $11^{\text {th }}$ century and ending with the $18^{\text {th }}$ century. 


\begin{tabular}{|c|c|c|c|c|c|c|c|c|c|c|c|c|c|c|c|c|}
\hline 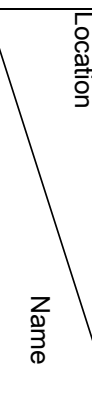 & 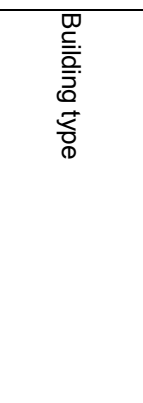 & 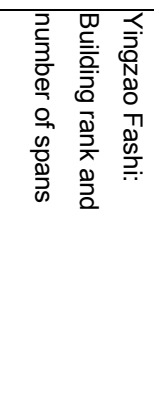 & 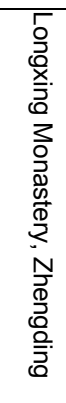 & 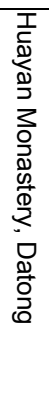 & 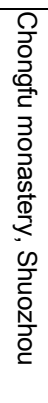 & 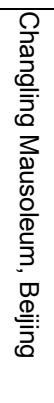 & 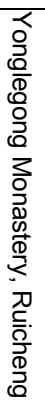 & 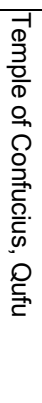 & 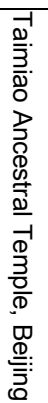 & 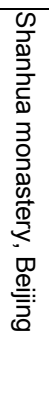 & 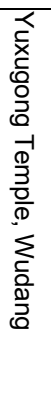 & 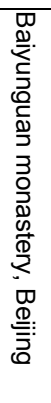 & 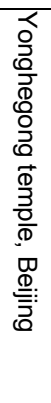 & 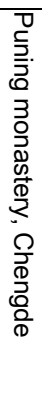 & Z & 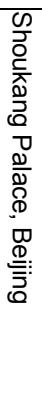 \\
\hline \multirow{2}{*}{ 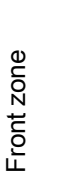 } & Gate & $\begin{array}{l}\text { rank IV } \\
3-5 \text { spans }\end{array}$ & & & & & & 5 & & & & & & & & \\
\hline & Gate & $\begin{array}{l}\text { rank IV } \\
3-5 \text { spans }\end{array}$ & & & & & & 5 & & & & & & & & \\
\hline \multirow{4}{*}{ 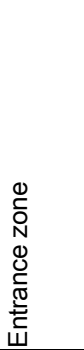 } & Main gate & $\begin{array}{l}\text { rank IV } \\
\text { 3-5 spans }\end{array}$ & 5 & 3 & 3 & 5 & 5 & 5 & 5 & 5 & 3 & 3 & & 5 & 5 & 1 \\
\hline & Arch / gate & $\begin{array}{l}\text { rank VII } \\
3 \text { spans }\end{array}$ & 3 & & & 3 & & 3 & 3 & & & 3 & 3 & 3 & 3 & \\
\hline & Arch & $\begin{array}{l}\text { rank VII } \\
3 \text { spans }\end{array}$ & & & & & & 3 & & & & & & & & \\
\hline & Arch & $\begin{array}{l}\text { rank VII } \\
3 \text { spans }\end{array}$ & & & & & & 3 & & & & & & & & \\
\hline
\end{tabular}

In general, the data in the table demonstrates that, as a rule, the number of jian buildings possessed corresponded to the recommendations of the Yingzao Fashi treatise, and only in some imperial complexes, such as the Imperial Ancestral Temple — the Taimiao — and Ningshougong Palace, the number of jian was higher than what the treatise prescribes, but given the significance of these structures, this is understandable. In other cases, the differences are associated with the peculiarities of the classification of the buildings, such as the Minglou tower at the Changling Mausoleum, or the palace gate in the female part of the Forbidden City. Table 1 also shows that in all given examples, the composition of architectural complexes develops from the entrance gates gradually, increasing to the central zone (or the highest zone if any), and then the measurement of structures towards the rear of the complexes decreases. And this system of construction does not depend on the intended purpose of a given architectural group, be it ritual, burial or palace complex.

\section{CONCLUSION}

An analysis of the use of the term jian in Chinese written sources showed that when describing wooden-framed buildings, it is used in the sense of "span" or "interval", that is to say, it denoted the distance or space in between adjacent supports or columns. At the same time, jian were also understood as a spatial unit, module, or cell, which included all the structures of the building located behind the façade jian. In this sense, jian were used to measure and record the size of architectural complexes, as well as to give account of damages caused by fires, wars, or natural decay. This is probably due to the fact that the calculation of the cost of structures, or the amount of damage incurred, was carried out based on the number of jian (i.e. the size of the building(s) measured in jian), and not by the actual number of buildings.

The number of jian in individual buildings was associated with prevailing rituals in China: in earlier buildings, as a rule, there was an even number of jian used, and, starting from the 5th century, the number of jian employed becomes increasingly odd. Apart from this, the number of jian was also a determining factor for the ranking of structures. The more significant the building, the more jian it possessed, up to the maximum number which one individual structure could reachthirteen jian, though practically, a single building rarely exceeded eleven jian. The smallest number of jian was one. In the treatise Yingzao Fashi, compiled in 1103, there is a detailed description of the relationship between the ranking of structures, and their quantity of spans. An analysis of the 
surviving architectural complexes showed that the rules described in that treatise continued to be applied until the end of the Qing dynasty.

\section{AUTHORS' CONTRIBUTIONS}

This paper is independently completed by Marianna Shevchenko.

\section{ACKNOWLEDGMENTS}

The author would like to express her deepest gratitude to Matfey Shaheen for translation of the article.

\section{REFERENCES}

[1] Sun Dazhang. The Art of Chinese House. Beijing: Zhongguo Jianzhu Gongye Publ, 2015, p.9. [in Chinese].

[2] Wang Peihuan, Chen Bochao. Imperial Palace of the Qing dynasty in Shenyang Beijing: Zhongguo Jianzhu Gongye Publ, 2015, p.67. [in Chinese].

[3] Taiping Yulan. Earth, part 4. Mount Taishan (Taiping Yulan, Dibu-Si, Taishan). Song Dynasty. [in Chinese]. URL: http://www.guoxuedashi.com/a/2973uumy/13 3893u.html

[4] Taiping Yulan. Change of Seasons, introduction. Midsummer (Taiping Yulan, Shixubu-Qi, Xiazhong). Song Dynasty. [in Chinese]. $\quad$ URL: http://www.guoxuedashi.com/a/2973uumy/13 3876j.html

[5] Zhou Suqing. The Forbidden City. Beijing: Zhongguo Jianzhu Gongye Publ, 2015, p.157. [in Chinese].

[6] Zhao Erxun. Qing Shi Gao. Vol.41. Beijing, 1927. [in Chinese]. URL: http://www.guoxuedashi.com/a/27tmwz/1248 12t.html

[7] Zhang Tingyu. History of Ming. Annals, vol. 5. Qing Dynasty. [in Chinese]. URL: http://www.guoxuedashi.com/a/325k/8481z.ht $\mathrm{ml}$

[8] Pan Guxi, He Jianzhong. Interpretation of the Yingzao Fashi. Nanjing: Dongnan Daxue Publ, 2005, p.40. [in Chinese].
[9] M. Shevchenko Origins of the Formation of Spatial Stereotypes in Chinese Architecture of the Zhou Era: XI - III centuries. BC, Middle and Lower Reaches of the Yellow River. (Istoki formoobrazovaniya prostranstvennyh stereotipov v arhitekture Kitaya epohi Zhou: XI - III vv. do n.e., srednee i nizhnee techenie reki Huanghe) PhD Thesises. Markhi, Moscow, 2006 [in Russian]

[10] Li Jie. Yingzao Fashi. Vol.5. Song Dynasty. [in Chinese]. URL: http://www.guoxuedashi.com/a/6247vgtk/839 $85 \mathrm{~m} . \mathrm{html}$

[11] M. Shevchenko Song Dynasty Gate Structure and Its Typology Reflected in the Paintings of Chinese Artists of 10th-13th Centuries. Proceedings of the 2nd International Conference on Art Studies: Science, Experience, Education (ICASSEE 2018). Pp. 448-455.

[12] Fu Xinian. Study of Planning Principles of Ancient Chinese Cities, Architectural Complexes and Single Buildings (Zhongguo Gudai Chengshi Guihua, Jiangzhuqun Buju ji Jianzhu Sheji Fangfa Yanjiu). Beijing: Zhongguo Jianzhu Gongye Publ, 2015. [in Chinese].

[13] Sun Dazhang. History of Ancient Chinese Architecture (Zhongguo Gudai Jianzhushi). Beijing: Zhongguo Jianzhu Gongye Publ, 2019. [in Chinese].

[14] Liang Sicheng. Qing Style Construction Rules (Qingshi Yingzao Zeli). Beijing: Qinghua Daxue Publ., 2006. [in Chinese]. 